\title{
Keefektifan Beberapa Isolat Bakteri Antagonis untuk Mengendalikan Penyakit Busuk Pangkal Batang pada Bibit Pepaya yang Disebabkan oleh Phythoptota palmivora
}

\author{
Efectiveness of Some Isolates of Bacterial Antagonists to Control Basal Stem Rot \\ of Papaya Seedling Caused by Phytophthora palmivora
}

\author{
Yeni Nurmaghfiroh ${ }^{1}$, Suryo Wiyono ${ }^{1,2^{*}}$ \\ ${ }^{1}$ Departemen Proteksi Tanaman Fakultas Pertanian Institut Pertanian Bogor Jl Meranti Darmaga, Bogor, Indonesia \\ ${ }^{2}$ Pusat Kajian Hortikultura Institut Pertanian Bogor Jl. Raya Pajajaran Baranangsiang, Bogor 16144, Indonesia
}

Diterima 31 Mei 2018/Disetujui 11 Juni 2018

\begin{abstract}
Basal stem rot caused by Phytophthora palmivora is an important disease of papaya in Indonesia. This research aimed to study the effectiveness of antagonistic bacteria to control root on papaya seedlings. This research was conducted in the Laboratory of Center for Tropical Horticulture Studies (PKHT), Bogor Agricultural University. Antagonistic bacterial isolates used were Bacillus cereus G4, Bacillus firmus $\mathrm{J}$, K1, Pseudomonas diminuta P14, and Psendomonas aeruginosa PA2. Antibiosis ability of all antagonistic bacteria was tested in vitro, by using dual culture test. Bioassay without pathogen inoculation was also performed to study the effect of tested bacteria on growth promotion of papaya seedlings. Effectiveness of five bacteria against basal stem rot was tested in a green house experiment with artificial inoculation of pathogens. Antagonistic bacteria was applied as seed trestment and watering at the rate of $10^{5} \mathrm{cfu} / \mathrm{ml}$. All antagonistic bacteria isolates suppressed the disease at the rate of $24.99-34.99 \%$. Bacillus cereus $G 4$ and Pseudomonas aeruginosa was able to increase growth of papaya seedlings.
\end{abstract}

Keyword: Bacillus, biological control, papaya, Phytophthora, Pseudomonas

\section{ABSTRAK}

Penyakit busuk pangkal batang yang disebabkan oleh Phytophthora palmivora merupakan penyakit penting pepaya di Indonesia. Penelitian ini bertujuan mempelajari keefektifan bakteri antagonis untuk mengontrol busuk akar pada bibit pepaya. Penelitian ini dilakukan di Pusat Kajian Hortikultura Tropika (PKHT), Institut Pertanian Bogor. Isolat bakteri antagonis yang digunakan yaitu Bacillus cereus $G 4$, Bacillus firmus $J 8, K 1$, Pseudomonas diminuta P14, dan Pseudomonas aeruginosa PA2. Kemampuan antibiosis seluruh bakteri antagonis diuji in vitro dengan menggunakan metode dual culture. Bioassay tanpa inokulasi patogen juga dilakukan untuk mempelajari bakteri dalam merangsang pertumbuhan bibit pepaya. Efektivitas lima bakteri terhadap penyakit busuk pangkal batang diuji dalam percobaan pada rumah kaca menggunakan inokulasi patogen buatan. Bakteri antagonis digunakan pada perlakuan benih dan penyiraman pada tingkat $105 \mathrm{cfu} \mathrm{ml}^{-1}$. Seluruh isolat bakteri antagonis mampu menekan penyakit $24.99-34.99 \%$. Bacillus cereus $G 4$ dan Pseudomonas aeruginosa mampu meningkatkan pertumbuhan pada bibit pepaya.

Kata kunci : Bacillus, pepaya, pengendalian biologi, Phytophthora, Pseudomonas

\section{PENDAHULUAN}

Pepaya (Carica papaya L.) merupakan komoditas buah tropika yang penting di Indonesia. Buah pepaya memiliki nilai nutrisi yang baik dan harga yang relatif terjangkau (Soenardi, 2005). Masyarakat sering mengkonsumsi pepaya dalam bentuk buah segar, bahan masakan, dan obat tradisional. Buah pepaya mengandung berbagai zat yang berguna bagi kesehatan manusia antara lain protein,

\footnotetext{
* Penulis untuk korespondensi. e-mail: suryowi269@gmail.com
}

vitamin $\mathrm{A}$, vitamin $\mathrm{C}$, kalsium, kalium, karbohidrat, dan memiliki kadar serat yang tinggi. Selain itu, getah pepaya mengandung lebih dari 50 asam amino dan enzim papain yang banyak digunakan untuk bahan industri makanan dan minuman, farmasi, kosmetik, tekstil, dan penyamak (Indriyani et al., 2008).

Pepaya menduduki peringkat keenam setelah pisang, mangga, nenas, jeruk, dan salak yakni sebesar 871,282 ton pada tahun 2013 (BPS 2013). Berbagai kegiatan pengembangan sering dilakukan untuk memperbaiki kualitas pepaya sehingga didapatkan pepaya dengan sifatsifat unggul. Salah satu masalah yang dihadapi dalam 
pengembangan pepaya yaitu adanya serangan penyakit yang bisa menurunkan produksi atau bahkan mematikan tanaman (Nazaruddin dan Muchlisah, 1996).

Salah satu patogen penting pepaya yaitu pseudofungi Phytophthora palmivora yang bisa menyerang bbit dan tanaman dewasa baik pada akar, batang dan buah. Gejala serangan yang muncul akibat patogen ini yakni terdapat pada akar dan pangkal batang yang terlihat busuk dan bau. Gejala awal yang muncul yakni daun bawah terlihat layu, menguning, dan menggantung di sekita batang. Selanjutnya daun-daun yang agak muda juga menunjukkan gejala yang sama sehingga tanaman terlihat hanya memiliki daun kecil di bagian pucuk. Bibit terserang parah akan mati. Penyakit ini terjadi apabila lingkungan sekitar memiliki kelembaban tinggi dan suhu udara panas. Penyebaran penyakit ini akan lebih cepat terjadi jika benih semai ditanam dengan jarak tanam rapat. $P$. palmivora termasuk pseudofungi penyebab penyakit pada banyak tanaman (Indriyani et al., 2008).

Pengendalian penyakit busuk pangkal batang sulit untuk dikendalikan karena infeks terjadi di dalam tanah. Gejala pada tajuk muncul ketika tanaman telah terserang dan terganggu perakarannya. Phytophthora palmivora sulit untuk dikendalikan secara kimiawi dengan menggunakan fungisida. Patogen ini memiliki sistem biokimia yang berbeda dengan true fungi dan berkembang pada kondisi lembab dan basah yang menyebabkan patogen ini sulit untuk dikendalikan dengan menggunakan fungisida (Drenth dan Guest, 2004). Salah satu teknik pengendalian yang potensial untuk penyakit busuk pangkal batang adalah dengan pengendalian hayati. Penelitian tentang bakteri antagonis untuk mengendalikan busuk pangkal batang sangat terbatas di Indonesia. Penelitian ini bertujuan mengetahui keefektifan bakteri antagonis dalam mengendalikan penyakit busuk pangkal batang yang disebabkan oleh Phytophtora palmivora dan pengaruhnya terhadap pertumbuhan bibit pepaya.

\section{BAHAN DAN METODE}

\section{Tempat dan Waktu}

Penelitian dilaksanakan di Laboratorium Hama Penyakit dan Rumah Kaca Pusat Kajian Hortikultura Tropika (PKHT), Kampus Institut Pertanian Bogor Baranangsiang. Penelitian ini dilaksanakan pada bulan Maret 2015 sampai dengan November 2015.

\section{Metode Penelitian}

Pembiakan Phytophthora palmivora

Pseudofungi patogen $P$. palmivora yang digunakan merupakan isolat koleksi dari Klinik Tanaman Departemen Proteksi Tanaman IPB. Isolat ini kemudian dibiakkan pada media Potato dextrose agar (PDA) dalam cawan petri.

\section{Pembiakan Bakteri Antagonis}

Bakteri antagonis yang digunakan merupakan isolat dari koleksi Klinik Tanaman Departemen Proteksi
Tanaman IPB. Isolat bakteri yang digunakan sebanyak lima jenis yakni Bacillus cereus G4, Bacillus firmus J8, K1 (belum diidentifikasi), Pseudomonas diminuta P14 dan Pseudomonas aeruginosa PA2. Isolat bakteri ini ditumbuhkan pada media Tripticase soy agar (TSA).

\section{Uji Antibiosis Bakteri Antagonis terhadap Phytophthora palmivora in vitro}

Uji antibiosis yang digunakan dengan teknik koloni ganda. Media yang digunakan dalam pengujian ini adalah media TSA dengan pH $6-6.5$. Isolat murni Phytophthora palmivora setelah mencapai pertumbuhan optimum diinokulasikan ke dalam cawan petri diameter $9 \mathrm{~cm}$ pada jarak $1 \mathrm{~cm}$ dari tepi kanan dan kiri sisi cawan. Bakteri antagonis diinokulasikan pada bagian tengah cawan. Pada perlakuan kontrol, media hanya diinokulasi dengan isolat pseudofungi. Zona bening yang berada diantara isolat bakteri dan pseudofungi diukur dengan penggaris. Pengukuran dilakukan setelah 7 hari sejak inokulasi bakteri dan pseudofungi pada media. Besarnya antibiosis bakteri uji dapat diketahui dengan mengukur lebar zona bening yang berada diantara bakteri antagonis dan pseudofungi $P$. palmivora. Pengukuran lebar zona bening dilakukan dengan bantuan penggaris, dilakukan 7 hari setelah perlakuan.

Uji Keefektivan ad planta Bakteri Antagonis dalam Mengendalikan Penyakit Busuk Pangkal Batang pada Bibit Pepaya

Tanah steril dan kompos steril dicampur dengan perbandingan 2:1 (v/v). Setiap tray diisi dengan media tumbuh sampai penuh dan rata dengan pinggiran atas tray. Pemeliharaan tanaman dilakukan dengan penyiraman tanaman secara berkala. Biakan bakteri berumur 48 jam dalam media TSA. Suspensi masing masing isolate bakteri dibuat dalam air steril dengan kepadatan $10^{5}$ cfu $\mathrm{mL}^{-1}$. Perlakuan bakteri antagonis dilakukan 2 kali, pertama dengan perendaman benih. Benih yang digunakan merupakan benih pepaya Calina. Benih papaya varietas Calina, direndam dengan suspensi bakteri pada kepadatan $10^{5} \mathrm{cfu} \mathrm{mL}^{-1}$ selama 15 menit, kemudian dipindahkan pada media tumbuh. Perlakuan kedua dilakukan dengan menyiram suspensi bakteri antagonis dengan kepadatan $10^{5}$ cfu $\mathrm{mL}^{-1}$ sebanyak $5 \mathrm{~mL}$ per tanaman, pada tanah sekitar batang saat bibit berumur 25 hari setelah tanam. Kontrol pada tahap inokulasi ini menggunakan aquadest steril untuk perendaman dan penyiraman.

Inokulum $P$. palmivora yang digunakan untuk pengujian berupa sporangia $P$. palmivora. $P$. palmivora ditumbuhkan pada media Potato Agar (PA) selama 7 hari. Selanjutnya diinkubasi pada suhu ruang dalam kondisi terang dan gelap 12:12 jam untuk pembentukan sporangia. Air steril ditambahkan di atas permukaan pseudofungi sebanyak $20 \mathrm{~mL}$ pseudofungi dipisahkan dari media agar dengan menggunakan kaca tipis yang digoreskan di atas media. Campuran miselium dan sporangia yang dikumpulkan 
dalam labu ernlemeyer kemudian dikocok dengan shaker $150 \mathrm{rpm}$ selama 10 menit, kemudian kemudian disaring dengan kain kasa sehingga diperoleh sporangia. Kepadatan sporangia dihitung dengan hemasitometer.

P. palmivora diinokulasi ke bibit pepaya umur 28 hari setelah tanam dengan cara menyiramkan suspense sporangia $10^{3}$ cfu $\mathrm{ML}^{-1}$ di daerah sekitar pangkal batang bibit pepaya. Bibit pepaya yang telah diinokulasi bakteri dan pseudofungi $P$. palmivora dipelihara, diamati, dan dihitung kejadian penyakit yang muncul. Pada pengujian ini terdapat dua jenis control yakni kontrol positif dan kontrol negatif. Pada kontrol positif, bibit hanya diberi perlakuan patogen P. palmivora tanpa adanya bakteri antagonis. Pada kontrol negatif, benih dan bibit tidak diberi perlakuan bakteri antagonis dan $P$. palmivora.

Pengamatan terhadap insidensi busuk pangkal batang bibit pepaya dilakukan setelah 7 hari perlakuan patogen $P$. palmivora. Insidensi penyakit yang terjadi dihitung dengan rumus yang dikemukakan Campbell dan Madden (1990) yaitu:

$$
\mathrm{IP}=\mathrm{n} / \mathrm{N}
$$

Keterangan : $\mathrm{IP}=$ kejadian penyakit $(\%), \mathrm{n}=$ jumlah tanaman terserang, $\mathrm{N}=$ jumlah tanaman yang diamati

\section{Pertumbuhan Bibit Pepaya dengan Berbagai Perlakuan Bakteri Antagonis}

Teknik perlakuan bakteri antagonis adalah seperti yang sudah diuraikan pada uji keefektivan bakteri antagonis terhadap penyakit, tetapi tidak menggunakan patogen. Pada umur 2 MST dilakukan penghitungan daya berkecambah benih. Pengamatan pertumbuhan pada bibit pepaya dilakukan saat bibit berumur 3 minggu setelah tanam (MST) dengan penghitungan jumlah daun, tinggi tanaman, dan diameter batang. Pada saat bibit berumur 4 MST, pengamatan dilakukan dengan penghitungan jumlah daun, tinggi tanaman, diameter batang, bobot basah tajuk, dan bobot basah akar.

Rancangan percobaan yang digunakan pada penelitian yakni rancangan acak lengkap untuk uji dual culture dan rancangan acak kelompok untuk metode in planta pada bibit pepaya serta uji pengaruh pertumbuhan. Semua data hasil pengamatan diolah dengan analisis ragam menggunakan program Microsoft Office Excel 2013 dan Statistical Analysis System (SAS) for windows versi 9.1.3. Uji lanjut menggunakan uji selang berganda Duncan pada taraf nyata $\alpha=0.05$.

\section{HASIL DAN PEMBAHASAN}

Kemampuan Antibiosis Bakteri Uji terhadap P. palmivora in vitro

Semua bakteri uji bersifat antibiosis terhadap $P$. palmivora, yang ditunjukkan adanya zona bening antara koloni bakteri uji dan P. palmivora (Tabel 1). Adanya zona bening menunjukkan bakteri uji memproduksi senyawa senyawa antimikrob (Susilowati 2011). Kemampuan antibiosis $P$. auruginosa PA 2, K1, dan Pseudomonas dimnuta P14 menghasilkan zona hambatan yang lebih besar dan berdeda nyata dengan Bacillus cereus G4.

\section{Keefektivan Bakteri Antagonis terhadap P. palmivora pada Bibit Pepaya secara in Planta}

Hasil penelitian menunjukkan bahwa penyakit pangkal batang pada bibit pepaya ini dapat diturunkan dengan perlakuan bakteri antagonis (Tabel 2). Salah satu mekanisme yang terlibat adalah semua bakteri yang diuji bersifat antibiosis terhadap $P$. palmivora (Tabel1). Penggunaan bakteri antagonis pada benih dapat meningkatkan kemampuan tanaman dalam bertahan dari infeksi patogen. Kemampuan bakteri mencapai jumlah populasi yang cukup di rhizosfer sangat penting dalam memberikan pengaruh untuk sifat-sifat bakteri yang menguntungkan pada kesehatan tanaman (Susilowati, 2011). Pseudomonas dan Bacillus ialah bakteri yang penting dari komunitas bakteri rhizosfer. Keberadaannya selalu berhubungan dengan penekanan penyakit. Kemampuan kelompok Pseudomonas untuk menekan pertumbuhan mikrob patogen tanah bergantung pada kemampuannya untuk menghasilkan antibiotik seperti pioluteorin, pirolnitrin, fenazin (Chin-AWoeng et al., 2003). Beberapa Pseudomonas spp. juga menghasilkan hydrogen sianida (Haas dan Keel, 2003), senyawa berberat molekul rendah yang disebut siderofor (O'Sullivan dan O'Gara, 1992; Loper dan Henkels, 1999) atau enzim kitinase dan glukanase (Saad, 2006). Namun beberapa bibit pada kontrol negatif terlihat terserang penyakit tersebut. Hal tersebut dapat terjadi akibat propagul yang terbawa air dari bibit yang diberi perlakuan $P$. palmivora di sekitar bibit kontrol positif pada saat pemeliharaan dengan penyiraman. Menurut Drenth dan Guest (2004), zoospora P. palmivora dapat aktif bergerak di air. Penyebaran dan penularan penyakit busuk akar dan pangkal batang dapat terjadi melalui aliran air tanah dan percikan air hujan pada tanah terinvestasi inokulum $P$. palmivora.

Pada penelitian ini, penekanan penyakit busuk pangkal batang tidak tinggi (24.99\%-34.99\%), meskipun menunjukkan perbedaan yang nyata dengan kontrol.

Tabel 1. Antibiosis beberapa bakteri antagonis terhadap P. palmivora secara in vitro.

\begin{tabular}{lc}
\hline \multicolumn{1}{c}{ Perlakuan } & Lebar zona bening $(\mathrm{cm})$ \\
\hline Bacillus cereus $\mathrm{G} 4$ & $0.31 \mathrm{a}$ \\
Bacillus firmus $\mathrm{J} 8$ & $1.21 \mathrm{ab}$ \\
$\mathrm{K} 1$ & $1.59 \mathrm{~b}$ \\
Pseudomonas diminuta $\mathrm{P} 14$ & $1.51 \mathrm{~b}$ \\
Pseudomonas aeruginosa PA2 & $1.58 \mathrm{~b}$ \\
\hline
\end{tabular}

Keterangan : Angka dengan huruf yang sama dalam satu kolom menunjukkan tidak berbeda nyata pada uji ragam berganda Duncan $(\alpha=0.05)$ 
Rendahnya penekanan penyakit diduga disebabkan oleh tekaan penyakit yang terlalu tinggi, yaitu kepadatan inokulum $10^{3}$ sporangia $\mathrm{mL}^{-1}$ serta lingkungan yang jenuh air terus. Selain itu, kemampuan kolonisasi P. palmivira tergolong cepat (Situmorang, 1983).

Suhu sangat mempengaruhi kecepatan pertumbuhan mikroba, kecepatan sintesis enzim dan kecepatan inaktivasi enzim (Knob dan Carmona, 2008). Setiap mikroba termasuk bakteri mempunyai suhu optimum, maksimum, dan minimum untuk pertumbuhannya. Jika suhu lingkungan lebih kecil dari suhu minimum atau lebih besar dari suhu maksimum pertumbuhannya maka aktivitas enzim akan terhenti bahkan pada suhu yang terlalu tinggi akan terjadi denaturasi enzim. Pertumbuhan mikroba optimum terjadi pada suhu dengan kisaran $30^{\circ} \mathrm{C}$. Kecepatan pertumbuhan bakteri dapat meningkat lambat karena faktor suhu pada lingkungan yang lebih kecil dari suhu minimum atau lebih besar dari suhu maksimum pertumbuhannya (Suriani et al., 2013). Pada penelitian ini, suhu lingkungan di sekitar pertanaman cukup tinggi pada saat siang hari. Rata-rata suhu di dalam rumah kaca mencapai $33.2{ }^{\circ} \mathrm{C}$. Kondisi tersebut

Tabel 2. Pengaruh beberapa isolat bakteri antagonis terhadap kejadian penyakit busuk akar pada bibit pepaya.

\begin{tabular}{lc}
\hline \multicolumn{1}{c}{ Perlakuan } & $\begin{array}{c}\text { Insidensi penyakit (\%) } \\
\text { pada 5 MST }\end{array}$ \\
\hline Bacillus cereus G4 & $45.00 \mathrm{~b}$ \\
Bacillus firmus J8 & $46.67 \mathrm{~b}$ \\
K1 & $50.00 \mathrm{~b}$ \\
Pseudomonas diminuta P14 & $43.33 \mathrm{~b}$ \\
Pseudomonas aeruginosa PA2 & $43.33 \mathrm{~b}$ \\
Kontrol + & $66.67 \mathrm{a}$ \\
Kontrol - & $26.67 \mathrm{c}$ \\
\hline
\end{tabular}

Keterangan : Angka dengan huruf yang sama dalam satu kolom menunjukkan tidak berbeda nyata pada uji ragam berganda Duncan $(\alpha=0.05)$ dapat memengaruhi keefektifan bakteri dalam menekan patogen pada tanaman karena kondisi suhu yang kurang sesuai dengan kebutuhan bakteri untuk berkembang.

Bakteri antagonis yang diuji masih berpotensi digunakan sebagai biocontrol. Peningkatan keefektivan pengendalian suatu antagonis bisa dilakukan dengan kombinasi isolat, perbaikan teknik aplikasi dan formulasi agens antagonis (Ramdan, 2014). Penggunaan gabungan beberapa antagonis berpeluang memiliki kemampuan yang hasilnya lebih baik dibanding hanya menggunakan antagonis secara tunggal, (Yigit dan Dikilitas, 2007).

\section{Pengaruh Bakteri Antagonis terhadap Pertumbuhan Bibit} Pepaya

Pengujian pada benih pepaya varietas Calina menunjukkan bahwa bakteri $B$. cereus G4 dan $P$. aeruginosa PA2 meningkatkan daya berkecambah benih pepaya mencapai $70-72 \%$ dibandingkan dengan kontrol (Tabel 3). Semua isolat bakteri yang diuji tidak berpengaruh terhadap semua variabel pertumbuhan bibit yang diuji baik pada diameter batang, tinggi tanaman, jumlah daun, bobot basah tajuk dan bobot basah akar. (Tabel 4 dan Tabel 5) .

Tabel 3. Pengaruh beberapa isolat bakteri terhadap daya berkecambah benih pepaya (tanpa patogen).

\begin{tabular}{lc}
\hline \multicolumn{1}{c}{ Perlakuan } & $\begin{array}{c}\text { Daya berkecambah } \\
(\%)\end{array}$ \\
\hline Bacillus cereus $\mathrm{G} 4$ & $72.50 \mathrm{a}$ \\
Bacillus firmus $\mathrm{J} 8$ & $64.17 \mathrm{ab}$ \\
$\mathrm{K} 1$ & $65.00 \mathrm{ab}$ \\
Pseudomonas diminuta $\mathrm{P} 14$ & $66.67 \mathrm{ab}$ \\
Pseudomonas aeruginosa PA2 & $70.83 \mathrm{a}$ \\
Kontrol & $52.50 \mathrm{~b}$ \\
\hline
\end{tabular}

Keterangan: Angka dengan huruf yang sama dalam satu kolom menunjukkan tidak berbeda nyata pada uji jarak berganda Duncan $(\alpha=0.05)$

Tabel 4. Pengaruh bakteri antagonis terhadap pertumbuhan bibit pepaya (tanpa patogen).

\begin{tabular}{lcccccc}
\hline \multirow{2}{*}{\multicolumn{1}{c}{ Perlakuan }} & \multicolumn{2}{c}{ Diameter batang $(\mathrm{mm})$} & \multicolumn{2}{c}{ Tinggi tanaman $(\mathrm{cm})$} & \multicolumn{2}{c}{ Jumlah daun } \\
\cline { 2 - 7 } & 3 MST & 4 MST & 3 MST & 4 MST & 3 MST & 4 MST \\
\hline Bacillus cereus G4 & 1.08 & 1.16 & 4.89 & 5.18 & 1.66 & 2.61 \\
Bacillus firmus J8 & 1.05 & 1.09 & 4.37 & 4.66 & 1.25 & 1.90 \\
K1 & 1.08 & 1.16 & 4.95 & 5.20 & 1.72 & 2.40 \\
Pseudomonas diminuta P14 & 1.09 & 1.18 & 4.94 & 5.22 & 1.67 & 2.50 \\
Pseudomonas aeruginosa PA2 & 1.09 & 1.09 & 5.06 & 5.06 & 1.8 & 2.35 \\
Kontrol + & 1.12 & 1.16 & 4.82 & 4.82 & 1.58 & 2.33 \\
\hline
\end{tabular}

Keterangan : Angka dengan huruf yang sama dalam satu kolom menunjukkan tidak berbeda nyata pada uji ragam berganda Duncan $(\alpha=0.05)$ 
Tabel 5. Pengaruh bakteri antagonis terhadap bobot basah tajuk dan bobot basah akar pada bibit pepaya (tanpa patogen)*.

\begin{tabular}{lcc}
\hline \multicolumn{1}{c}{ Perlakuan } & $\begin{array}{c}\text { Bobot tajuk } \\
(\mathrm{g})\end{array}$ & $\begin{array}{c}\text { Bobot akar } \\
(\mathrm{g})\end{array}$ \\
\hline Bacillus cereus G4 & 0.2 & 0.04 \\
Bacillus firmus $\mathrm{J} 8$ & 0.15 & 0.03 \\
K1 & 0.21 & 0.04 \\
Pseudomonas diminuta P14 & 0.2 & 0.03 \\
Pseudomonas aeruginosa PA2 & 0.2 & 0.03 \\
Kontrol - & 0.17 & 0.03 \\
\hline
\end{tabular}

Keterangan: Angka dengan huruf yang sama dalam satu kolom menunjukkan tidak berbeda nyata pada uji jarak berganda Duncan $(\alpha=0.05)$, *Umur 4 MST

Hal ini diduga disebabkan bakteri yang diuji dominan menghasilkan zat pengatur tumbuh seperti IAA. Berbagai bakteri yang bersifat PGPR Plant Growth Promoting Rhizobacteria memiliki kemampuan menyediakan dan memobilisasi atau memfasilitasi penyerapan berbagai unsur hara dalam tanah, serta mensintesis dan mengubah konsentrasi berbagai fitohormon pemacu pertumbuhan (Bhanttacharyya dan Jha, 2012). Beberapa bakteri tanah telah dilaporkan mampu menghasilkan hormon tumbuh indol acetil acid (IAA), mensekresikan siderofor, melarutkan fosfat, dan berperan sebagai agen pengendali hayati terhadap fungi patogen tanaman yaitu rizobacteri dari kelompok Bacillus spp. dan Pseudomonas spp. (Budi dan Mariana, 2009).

\section{KESIMPULAN}

Semua bakteri antagonis yang diuji yaitu Bacillus cereus G4, Bacillus firmus J8, K1, Pseudomonas diminuta P14 dan Pseudomonas aeruginosa PA2 mampu mengendalikan penyakit busuk pangkal batang yang disebabkan Phytophthora palmivora pada bibit pepaya dengan tingkat pengendalian berturut turut $32.5 \%, 29.98 \%$, 24.99\%, 34.99 \% dan 34.99\%. Salah satu mekanisme penekanan penyakit busuk akar oleh bakteri antagonis yakni dengan antibiosis. Bakteri antagonis Bacillus cereus G4 dan Pseudomonas aeruginosa PA2 mampu meningkatkan daya berkecambah benih pepaya.

\section{DAFTAR PUSTAKA}

[BPS] Badan Pusat Statistik. 2013. Produksi buahbuahan menurut provinsi. http://ww.bps.go.id/ tab_sub/view.php?kat=3\&tabel=1\&daftar=1\&id_ subyek=55\&notab=10. [4 Juni 2014].

Bhanttacharyya, P.N., D.K. Jha. 2012. Plant promoting rhizobacteria (PGPR) : emergence in agriculture. World J Microbiol Biotechnol. 28:1327-1350.
Budi, L.S., Mariana. 2009. Formulasi Biopestisida Berbahan Aktif Jamur Endofitik untuk Pengendalian Penyakit Busuk Batang Padi (Rhizoctonia solani). Universitas Lambung Mangkurat. Banjarbaru.

Campbell, C.L., J.W. Madden. 1990. Introduction to Plant Diseases Epidemiology. John Wiley and Sons. New York, USA.

Campbell, C.L., D.M. Benson. 1994. Epidemiology and Management of Root Diseases. North Carolina State University. North Carolina (US).

Chin-A-Woeng, T.F.C., G.V. Bloemberg., B.J.J. Lugtenberg. 2003. Phenazine and their role in biocontrol by Pseudomonas bacteria. New Phytologist. 157:503523.

Compant, S., B. Duffy, J. Nowak, S. Clement, E.A Barka. 2005. Use of plant growth promoting bacteria for biocontrol of plant disease : principle, mechanisms of reaction, and future prospect. Appl Environ Microbiol. 71:4951-4959.

Drenth, A., D.I. Guest. 2004. Diversity and Management of Phytophthora in Southeast Asia. Australia Centre for International Agricultural Research. Canberra (AU)

Dwidjoseputro. 1994. Dasar-dasar Mikrobiologi. Djambatan. Jakarta.

Haas, D., C. Keel. 2003. Regulation of antibiotic production in root-colonizing Pseudomonas spp., relevance for biological control of plant disease. Annu Rev Phytopathol 41:117-153.

Indriyani, N.L.P., Affandi, S. Diah. 2008. Pengelolaan Kebun Pepaya Sehat. Balai Penelitian Tanaman Buah Tropika. Solok.

Khalim, K., G.N.A.S, Wirya. 2009. Pemanfaatan plant growth promoting rhizobacteria untuk biostimulans dan bioprotectans. Ecotropic. 4(2):131-135.

Knob, A., E.C. Carmona. 2008. Xylanase production by Penicillium sclerotiorum and its characterization. World Appl Scie J. 4(2):277-283.

Loper, J.E., M.D. Henkels. 1999. Utilization of heterologous siderophores enhances levels of iron available to Pseudomonas putida in the rhizosphere. Appl Environ Microbiol. 65:5357-5363.

Maria, P.D. 2002. Eksplorasi dan uji antagonisme bakteri rhizosfer tanah dan endofit akar untuk pengendalian penyakit layu (Fusarium oxysporum f.sp cubense) pada pisang (Musa paradisiaca). Skripsi. Institut Pertanian Bogor. Bogor. 
Nasikhah K. 2008. Pengaruh isolat alami Pseudomonas fluorescens pada beberapa tingkat pengenceran terhadap jamur Sclerotium rolfsii penyebab penyakit layu pada kedelai (Glycine max (L) Merill). Skripsi. Universitas Islam Negeri Malang. Malang.

Nazaruddin, F. Muchlisah. 1996. Buah Komersial. Penebar Swadaya. Jakarta.

O’Sullivan, D., F. O'Gara. 1992. Traits of fluorescent Pseudomonas spp. involved in suppression of plant root pathogens. Microbiol Rev. 56:662-676.

Ramdan, E.P. 2014. Eksplorasi cendawan endofit sebagai agens pengendali hayati Phytophthora capsici Leonian pada cabai. Tesis. Institut Pertanian Bogor. Bogor.

Rustam. 2012. Potensi bakteri penghasil senyawa bioaktif anticendawan untuk pengendalian penyakit hawar pelepah padi. Disertasi. Institut Pertanian Bogor. Bogor.

Saad, M.M. 2006. Destruction of Rhizoctonia solanis and Phytophthora capsici causing tomato root-rot by Pseudomonas fluorescens lytic enzymes. Res J Agric Biol Sci. 2:274-281.

Situmorang, A. 1983. Daya tahan hidup Phytophthora palmivora Butl. Penyebab penyakit bidang sadap Hevea brasilensis Muell. di dalam tanah. Tesis. Institut Pertanian Bogor. Bogor.
Soenardi, T. 2005. Pepaya sehatkan sperma. http://www. kompas.com/kesehatan/news/0509/29/095824.thm [3 Juni 2014].

Suriani, S., Soemarno, Suharjono. 2013. Pengaruh suhu dan $\mathrm{pH}$ terhadap laju pertumbuhan lima isolat bakteri genus Pseudomonas yang diisolasi dari ekosistem sungai tercemar deterjen di sekitar Kampus Universitas Brawijaya. J-PAL. 3(2):58-62.

Susilowati, A. 2011. Karakterisasi fisiologi dan genetik Pseudomonas sp. sebagai biokontrol penyakit cendawan tular tanah pada tanaman kedelai. Disertasi. Institut Pertanian Bogor. Bogor.

Supriatin, Y.2008. Kajian produksi biogas skala laboratorium dengan inokulum konsorsium alami metanogen dalam substrat bungkil jarak pagar (Jatropha curcas L.) [tesis]. Institut Teknologi Bandung. Bandung.

Umrah, T. Anggraeni, R.R. Esyanti, I.N.P. Aryantha. 2009. Antagonisitas dan efektivitas Trichoderma sp. dalam menekan perkembangan Phytophthora palmivora pada buah kakao. J Agroland. 16(1):9-16.

Wahyuni, W.S., A. Mudjiharjati, N. Sulistyaningsih. 2010. Compost extracts of vegetable wastes as biopesticide to control Cucumber mosaic virus. J of Biosciences. 17(2):95-100.

Yigit, F., Dikilitas. 2007. Control of Fusarium wilt of tomato by combination of fluorescent pseudomonads, nonpathogen Fusarium and Trichoderma harzianum T-22 in greenhouse conditions. J Plant Pathology. 6:159-163. 